\title{
Ecological classification for mountain forest sustainability in northeast China ${ }^{1}$
}

\author{
by Limin $\mathrm{Dai}^{2}$, Guofan Shao ${ }^{3}$ and Baoying Xiao ${ }^{4}$
}

\begin{abstract}
This paper introduces the classification of Ecological Land Types (ELT) in eastern mountainous regions of northeast China and demonstrates ELT mapping for the Baihe Forestry Bureau on Changbai Mountain, lying along the border of China and North Korea. The development of ELTs will facilitate the adoption of ecological forest management and the restoration of native forest vegetation in northeast China. By overlaying forest inventory data with the ELT map, suggestions on ecosystem forest management are discussed in this paper.
\end{abstract}

Key words: China's forestry, ecosystem management, ecological land types, geographic information systems, digital elevation models

Cet article introduit la classification des types de territoires écologiques (TTE) dans les régions orientales montagneuses du nordest de la Chine et fait la démonstration de la cartographie TTE pour le bureau forestier de Baihe sur le mont Changbai qui se situe le long de la frontière entre la Chine et la Corée du Nord. Le développement des TTE facilitera l'adoption d'un aménagement forestier écologique et la restauration de la végétation forestière indigène dans le nord-est de la Chine. En superposant les données d'inventaire forestier sur les cartes de TTE, cet article présente des suggestions en matière d'aménagement forestier écosystémique.

Mots-clés : foresterie chinoise, aménagement écosystémique, types de territoires écologiques, systèmes d'information géographique, modèles numériques d'altitude

\section{Introduction}

In 1954, China started to build state-owned forest industries, whose task was to harvest timber from old-growth forests in northeast and southwest China. Nationwide forest harvesting was operated on the basis of some simple rules developed by the central government in 1956 and revised in 1987. Although the nationwide rules were formulated just for the purpose of timber

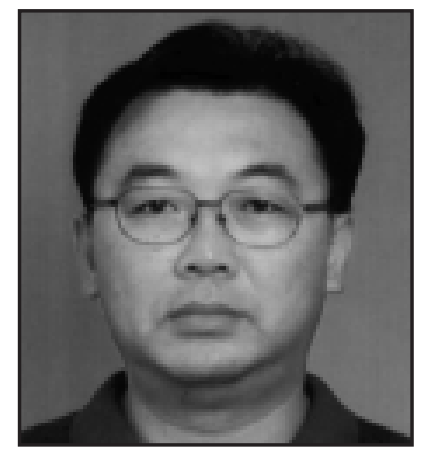

Limin Dai harvesting, they stipulated different methods of forest harvesting under different topographic conditions. For example, clearcutting should be used if slope is less than $35^{\circ}$, otherwise, selective cutting is to be applied (Shao et al. 2001). However, the regulation ignored the fact that slopes greater than $35^{\circ}$ were common in southwest China but rare in northeast China. As a result, clearcutting was used almost exclusively throughout northeast China. Many forested landscapes, formerly covered with contiguous uneven-aged and mixed forests, became monoculture plantations. Due to China's diverse biogeographical conditions and the variations in forest vegetation from north to south and

1Paper presented at "Mountain Forests: Conservation and Management," IUFRO Silviculture Conference, Vernon, British Columbia, Canada, July 28-August $1,2002$.

${ }^{2}$ Institute of Applied Ecology, Chinese Academy of Sciences, 72 Wenhua Road, Shenyang 110015, P. R. China. E-mail: Imdai@iae.ac.cn (Corresponding author) ${ }^{3}$ Department of Forestry and Natural Resources, 1159 Forestry Building, Purdue University, West Lafayette, IN 47907, USA

${ }^{4}$ Institute of Applied Ecology, Chinese Academy of Sciences, 72 Wenhua Road, Shenyang 110015, P. R. China.

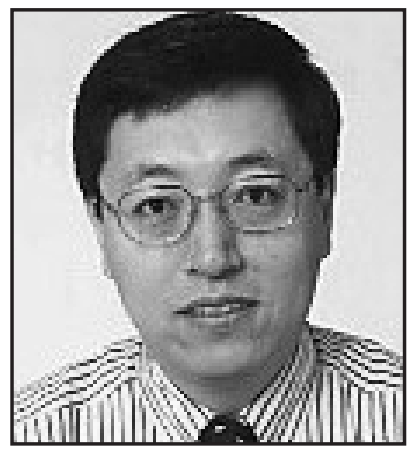

Guofan Shao

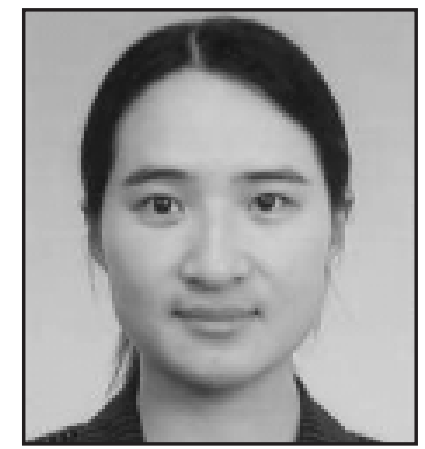

Baoying Xiao from east to west, it was evident that any single forest regulation could not satisfy the need to implement ecological management of forest resources across the country.

Growing pressures on forest lands to provide products and amenities have resulted in increasing interest in Ecological Classification Systems (ECS) to provide the ecological context for management decisions (Barnes et al. 1982). Ecological classification of forest lands has become a precondition to ecosystem management of forests (Moores et al. 1996). The hierarchical framework of ecological units developed by ECOMAP (1993) is the principle guide for ECS development in the United States. In Canada, ecological classification has been used to report forest health (Hirvonen 2001) and pursue sustainable forest management (Hall 2001). In the US, ECS is being broadly used for managing National Forests (Jenkins and Parker 1998).

Although ECS has been adopted in many countries, its concepts and applications are still relatively new in China. Shao et al. (2001) proposed to use a bottom-up approach to develop ECS in China by referring to the framework described by 
Table 1. An ELT classification in northeast China

\begin{tabular}{|c|c|c|c|c|}
\hline Elevation (m) & Aspect (Azimuth) & Slope (Degree) & ELT \# & Description \\
\hline$\leq 1000$ & - & -5 & 1 & Low Elevation Bottomlands \\
\hline$\ldots$ & $\leq 135$ or $>315$ & $5-25$ & 2 & Low Elevation-Mesic-Gentle Slopes \\
\hline$\ldots$ & $135-315$ & $5-25$ & 3 & Low Elevation-Dry- Gentle Slopes \\
\hline$\ldots$ & $135-315$ & $>25$ & 4 & Low Elevation-Dry- Steep Slopes \\
\hline$\ldots$ & $\leq 135$ or $>315$ & $>25$ & 5 & Low Elevation-Mesic-Steep Slopes \\
\hline$>1000$ & - & $\leq 5$ & 6 & High Elevation Bottomlands \\
\hline$\ldots$ & $\leq 135$ or $>315$ & $5-25$ & 7 & High Elevation-Mesic-Gentle Slopes \\
\hline$\ldots$ & $135-315$ & $5-25$ & 8 & High Elevation-Dry-Gentle Slopes \\
\hline$\ldots$ & $135-315$ & $>25$ & 9 & High Elevation-Dry-Steep Slopes \\
\hline$\ldots$ & $\leq 135$ or $>315$ & $>25$ & 10 & High Elevation-Mesic-Steep Slopes \\
\hline
\end{tabular}

ECOMAP (1993). A pioneer research project was conducted in northeast China to examine the significance and feasibility of ECS development in China. This paper introduces the classification of Ecological Land Types (ELT) in eastern mountainous regions of northeast China and demonstrates the ELT mapping and its applications at the Baihe Forestry Bureau on Changbai Mountain, lying along the border of China and North Korea.

\section{Classification Criteria and Threshold}

ELT is one of the basic ecological units and is particularly useful for forest management planning and analysis at land unit scales (ECOMAP 1993). The development of ELTs aims at the implementation of ecosystem management of forests in northeast China. ELT classification system should meet the following criteria:

1. The procedures of ELT classification should be explicit enough that ELTs can be readily mapped with available information and data sources.

2. The threshold of ELT classification should be general enough so that it will be applicable over extensive areas of northeast China.

3. The factors of ELT classification should be linked to past forest classifications when possible so that reference can be made to past experience in forest management.

4. ELT classification should be consistent with the objectives of ongoing forestry programs, including the Natural Forest Conservation Program (NFCP) and Returning Farmlands to Forests Program (RFFP) (Shao et al. 2003).

Land surface form that influences hydrologic function is often used to delineate different ELTs in mountainous terrain (ECOMAP 1993). Commonly used physiographic factors are slopes and aspects (e.g., Van Kley et al. 1995) because managed forests on the eastern mountains of northeast China are distributed in two elevational zones: broadleaved-coniferous forest and coniferous forest. Elevation should be the third factor for ELT classification in northeast China.

Slopes are categorized in three classes: $<5^{\circ}, 5-25^{\circ}$ and $>25^{\circ}$. Slopes $<5^{\circ}$ are generally considered flatlands, largely occur in catchments, and are called bottomlands in this study. Because the NFCP requires protection of forests growing on slopes greater than $25^{\circ}$ in northeast China and the threshold for farmlands-to-forests conversion in RFFP is also set to be $25^{\circ}$, terrains need to be divided into gentle slopes $\left(5-25^{\circ}\right)$ and steep slopes $\left(>25^{\circ}\right)$.

Slope orientation or aspect affects evapotranspiration and in turn, tree species compositions. Two aspect classes are necessary. The first class is mesic aspect, including north- and east-fac- ing aspects. The azimuth of mesic aspect ranges from $0-135^{\circ}$ and $315-360^{\circ}$. The second class is dry aspect, including southand west-facing aspects between $135-315^{\circ}$ in azimuth.

The altitude division line of the mixed forest and coniferous forest zones is located at an elevation of $900 \mathrm{~m}$ in the north (Xiaoxingan Mountain) and $1100 \mathrm{~m}$ in the south (Changbai Mountain). The mean of the two values, $1000 \mathrm{~m}$, is generally recognised in northeast China as a threshold for elevation.

By combining the three factors, ten ELTs can be derived $(2 \times(2$ $\times 2+1)=10)($ Table 1$)$.

\section{ELT Mapping}

ELT mapping methods were tested at Jinsong Sub-Forestry Bureau of Baihe Forestry Bureau on Changbai Mountain, lying along the border of China and North Korea. Located in eastern Jilin Province, the Baihe Forestry Bureau is a typical state-owned forest enterprise covering over 200000 ha. The centre of the bureau is located at $42^{\circ} 26.63^{\prime} \mathrm{N}, 128^{\circ} 26.56^{\prime} \mathrm{E}$.

Digital Elevation Models (DEM) with 20-m cell sizes were used to extract slope, aspect, and elevation information needed for ELT mapping. Mapping processes were accomplished with ArcView GIS software (www.esri.com). Slopes, aspect, and elevations were grouped to three, two, and two classes, respectively, according to the thresholds above. An ELT map was derived with the overlays of the three discrete data layers.

The entire test area was dominated by ELT 1-3 (Fig. 1). ELT1 (Low Elevation Bottomlands) accounted for $21 \%$ of total test area; ELT2 (Low Elevation-Mesic-Gentle Slopes) 32\%; ELT3 (Low Elevation-Dry-Gentle Slopes) 28\%. The other two lowelevation ELTs accounted for $6 \%$ of total test area. For the highelevation ELTs, the bottomlands and gentle slopes accounted for $12 \%$ of total test area and the rest are steep slopes, which accounted for only $1 \%$ of total test area.

The ELT map was validated with data collected from 480 plots, $20 \times 30 \mathrm{~m}$ in size (Fig. 1). The plots were systematically set up at an interval of $500 \mathrm{~m}$. The accuracy of ELT1-3 exceeded $90 \%$ but the accuracy of other smaller ELTs in area varied partially because they were checked against relatively smaller samples. In the final analysis, the major "errors" could be caused by low-accuracy GPS (Global Positioning System) measurements because they all occurred near boundaries between neighbouring ELTs.

\section{ELT Applications}

ELTs are important to understand potential distribution of species and, therefore, potential productivity of forest ecosystems. By overlaying the ELT map with forest inventory data provided by the Baihe Forestry Bureau, the existing forest man- 


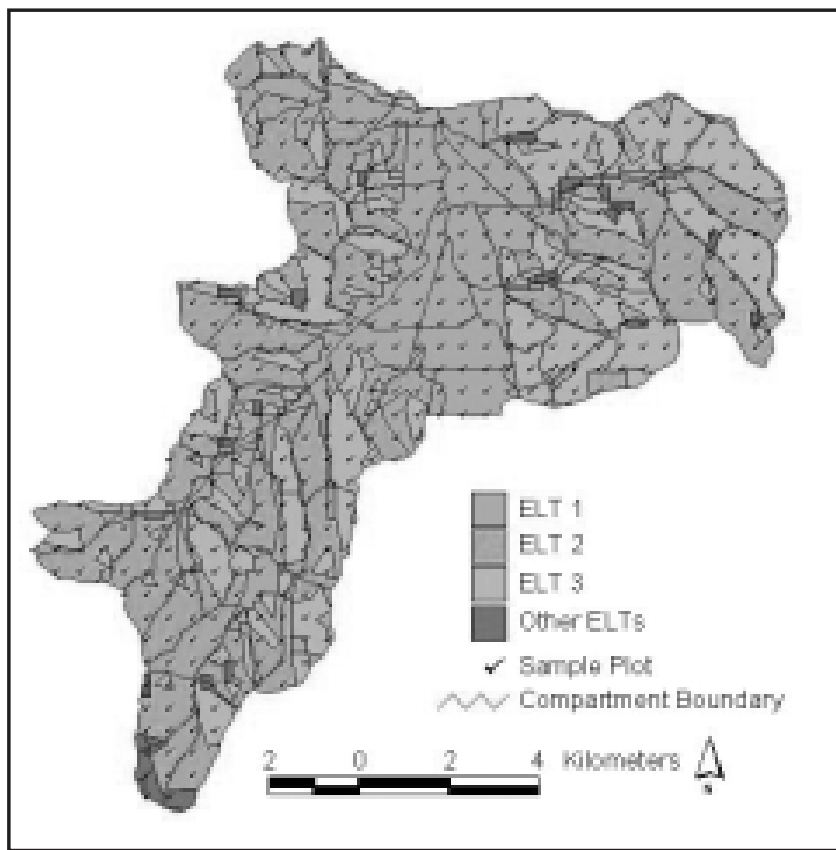

Fig. 1. An overlay of ELTs, compartments and sample points in Jinsong Sub-Forestry Bureau.

agement units (i.e., compartment and sub-compartment maps) were revised. The resulting sub-compartment polygons, the basic forest management unit, contained ELT information in the attribute tables. By comparing the current and potential forest types determined by ELTs, it was possible to determine forest management schemes suitable for the goals of ecosystem management of forested landscapes (Fig. 2). Based on the composition of the existing and potential vegetation types in the region (Shao and Zhao 1998), the ten ELTs were grouped into manageable and protective ELTs. The former included the four gentle-slope ELTs and was the target of intensive management; the latter included the bottomland and steep-slope ELTs and required little management.

The major vegetation found in the bottomland ELTs included bogs and wetland forests. Dominant tree species were Alnus mandshurica, Betula platyphylla, Larix olgensis, and Abies nephrolepis. Well-protected bogs and wetland forests are important habitat for rare and endangered wildlife species, such as Chinese quisha duck (Mergus squdmatus) (Shao and Zhao 1998). Because Changbai Mountain is the origin of three major river systems, vegetation in the bottomland ELTs functions as a filter and protects soil (from erosion) and water supplies in northeast China. Since all the residential areas and frog ponds are found in the bottomland ELTs, new management measures are needed to protect and restore wetlands and wetland forests in the Baihe Forestry Bureau.

The steep-slope ELTs are normally found near mountain ridges, where soil is shallow and rocky. Forests on steep-slope ELTs consist of mainly Pinus koraiensis, Tilia amurensis, and Quercus mongolica in low elevations and Picea koraiensis and Betula costata in high elevations. These forests are considered ecologically sensitive because harvesting can cause severe soil erosion and, further, inhibit their restoration. Ecologically sensitive forests are protection targets in NFCP (Zhang et al. 2000). The collection of Korean pine seeds should be regulated to provide seed banks.

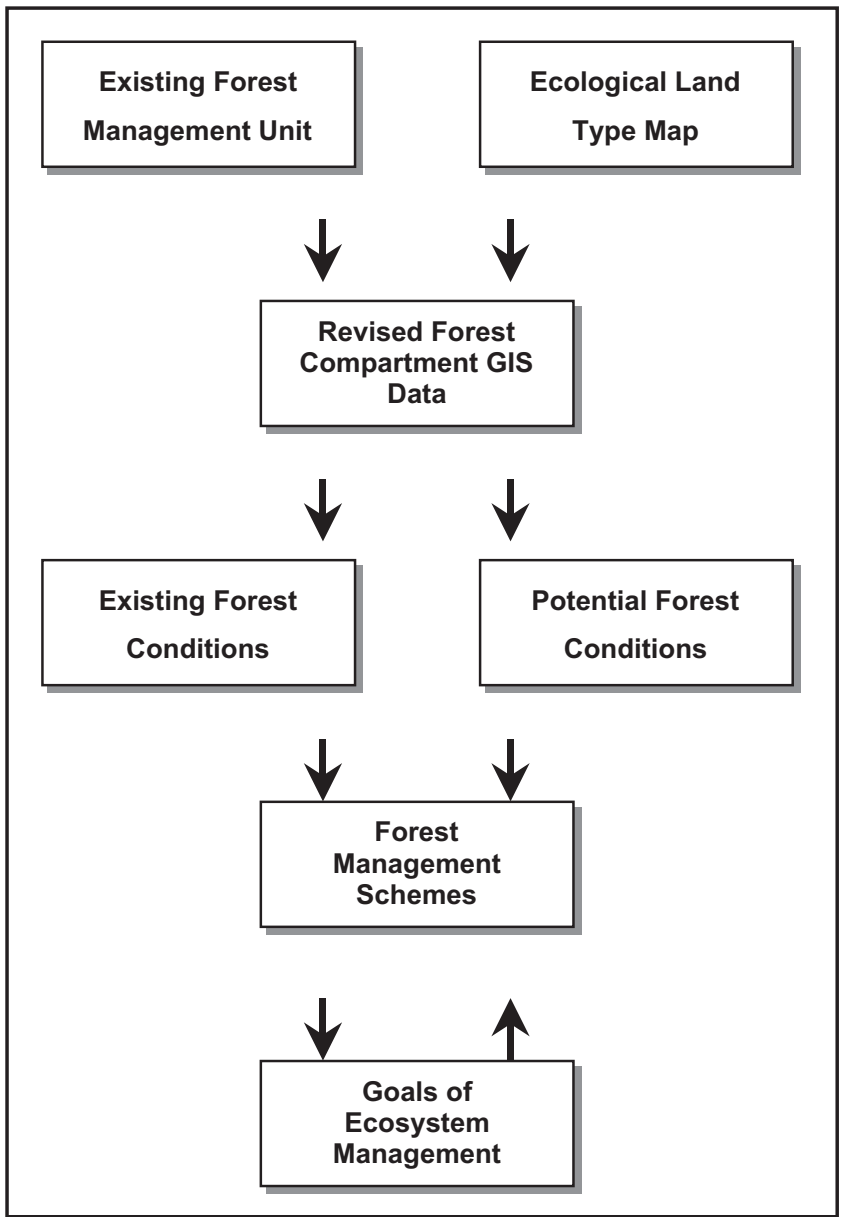

Fig. 2. An illustrative explanation of ELT applications in forest management.

In the test area, manageable ELTs count for 69\% of total area. Forests on these ELTs have not only high productivity, but also high species diversity. They are the most suitable habitat of the Manchurian tiger (Panthera tigris subsp. longipilis) but no tiger has been seen in the region for years. The management of these forests should consider the potential for the restoration of wildlife species such as the tiger. Selective cutting is ecologically and long-term economically the best approach for the uneven-aged mixed forests (Shao et al. 1996). There are differences in tree species composition between dry and mesic ELTs. Forest management should promote the regeneration and growth of physiographically suitable tree species, such as Korean pine on ELT2 and Mongolian oak on ELT3. Openings of less than 5 ha should be utilized and may be artificially regenerated if natural regeneration is not sufficient. The past "small-area" clearcutting approaches were not recommended because the cutting area was too large ( $>15$ ha) and remaining forests between cutting areas were too distant (Shao and Zhao 1998). When clearcutting is used for developing high-production forest plantations, the size of cutting areas of should be restricted to less than 5 ha and the spatial distribution of cutting areas should be based on landscape functionality. For example, forests near bottomland ELTs are unsuitable for clearcutting. 


\section{Conclusions}

ELT classification is the initial step toward ecosystem management of forests in northeast China. Nevertheless, the applications of ELT classification and mapping can improve ecological values of the forest management system that has lasted for decades in northeast China. The processes of ELT classification and mapping are straightforward in methodology and feasible with the current information. The 20-m resolution DEMs useful for ELT mapping are available from China Survey and Mapping Bureau with minor costs. It is technically and economically feasible for local forestry units to apply ELTs.

The comparison of the existing and proposed forest conditions through overlaying forest inventory data and ELT maps can be used to develop ecologically sound forest management schemes. These forest management schemes are spatially explicit and, therefore, are relatively more convincing and easier to execute in practice. Although there are only ten ELTs, their proportions and spatial mixtures vary among forestry units. Different forestry units will, therefore, need to develop individual forest management plans. To assure landscape considerations, higher-level forestry units need to co-ordinate forest planning with lower-level forestry units. The sophisticated planning processes can be carried out with assistance of a decision support system that is currently under development (Shao et al. 2003).

\section{Acknowledgements}

Authors would like to thank the Baihe Forestry Bureau and Jinsong Sub-Forestry Bureau for providing assistance in field data collection. The research was financially supported by "100-people" project and innovated project from Chinese Academy of Sciences. ELT classification was supervised by Dr. George Parker at Purdue University, USA.

\section{References}

Barnes, B.V., K.S. Pregitzer, T.A. Spies and V.H. Spooner. 1982. Ecological forest site classification. J. For. 80 (8): 493-498. ECOMAP. 1993. National Hierarchical Framework of Ecological Units. ECOMAP, USDA Forest Service, Washington, D.C. 28 p.

Hall, J.P. 2001. Criteria and indicators of sustainable forest management. Environ. Monit. Assess. 67 (1-2): 109-119.

Hirvonen, H. 2001. Canada's national ecological framework: an asset to reporting on the health of Canadian forests. For. Chron. 77(1): 111-115. Jenkins, M.A. and G.R. Parker. 1998. Composition and diversity of woody vegetation in silvicultural openings of southern Indiana forests. Forest Ecology and Management 109: 57-74.

Moores, L.J., B. Pittman and G. Kitchen. 1996. Forest ecological classification and mapping: Their application for ecosystem management in Newfoundland. Environ. Monit. Assess. 39 (1-3): 571-577.

Shao, G., S. Zhao and H.H. Shugart. 1996. Forest dynamics modeling: preliminary explanations of optimizing management of Korean pine forests. China Forestry Publishing House. 170 p. (In Chinese with English table titles and figure captions.)

Shao, G. and G. Zhao. 1998. Protecting versus harvesting of oldgrowth forests on the Changbai Mountain (China and North Korea): A remote sensing application. Natural Areas Journal 18(4): 334-341. Shao, G., P. Zhang, G. Bai and Z. Wang. 2001. Ecological classification systems for protection and management of China's Natural forests. Acta. Ecol. Sinica 21 (9): 1564-1568. (In Chinese.)

Van Kley, J.E., G.R. Parker, D.P. Franzmeier and J.C. Randolph. 1995. Field guide: Ecological classification of the Hoosier National Forest and surrounding areas of Indiana. USDA Forest Service, North Central Forest Experiment Station. 113 p.

Zhang, P., G. Shao, G. Zhao, D.C. LeMaster, G.R. Parker, J.B. Dunning and Q. Li. 2000. Ecology: China's Forest Policy for the 21st Century. Science 288 (5474): 2135-2136. 